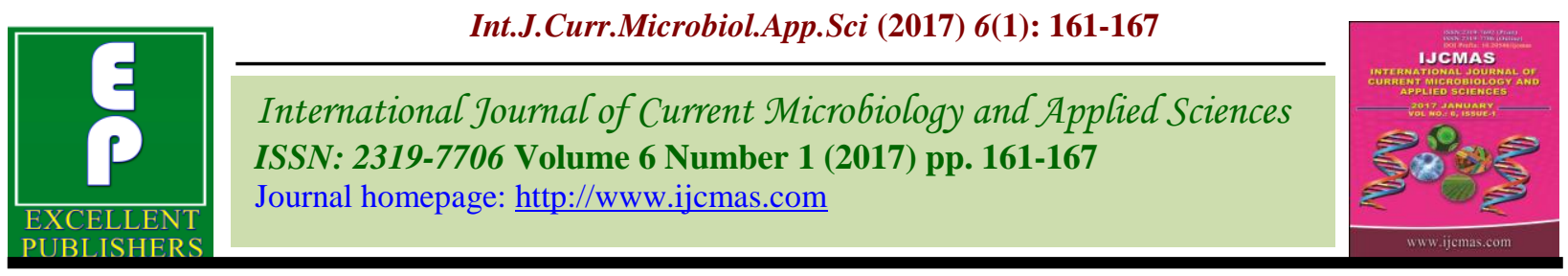

Original Research Article

http://dx.doi.org/10.20546/ijcmas.2017.601.020

\title{
Allelopathic Effect of Moringa peregrina Forssk. on Germination and Early Seedling Development of Two Common Food Intercrops
}

\author{
Ameera Ameen Aytah* \\ Department of Botany and Biology, Faculty of Science, Tiba University, Saudi Arabia \\ *Corresponding author
}

\begin{tabular}{|c|c|}
\hline & A B S T R A C T \\
\hline $\begin{array}{l}\text { Allelopathy, } \\
\text { Moringa peregrine, } \\
\text { Hordeum vulgare, } \\
\text { Trigonellafoenum- } \\
\text { graecum. }\end{array}$ & \multirow{3}{*}{$\begin{array}{l}\text { The present study aims at evaluating the possible allelopathic potential of Moringa } \\
\text { peregrine Forssk. on some growth attributes of two economically important food crops; } \\
\text { Hordeum vulgare and Trigonellafoenum-graecum. The results indicate that } \\
\text { Hordeumvulgareis more sensitive to Moringa peregrine leaves aqueous extract than } \\
\text { Trigonellafoenum-graecum, and a concentration of } 2.5 \% \text { of that extract express the } \\
\text { highest allelopathic effect on the degree of inhibition on seed germination of Hordeum } \\
\text { vulgare. Radicle lengths of both recipient species were largely dependent on the } \\
\text { concentration of the extracts of the donor species where it decreased with increasing the } \\
\text { extract concentration. Highest reductions were achieved using } 10 \% \text { aqueous extracts. The } \\
\text { effect was statistically significant at p } \leq 0.001 \text { for most treatments. In conclusion, the } \\
\text { cultivation of Moringa peregrine accompanied with Hordeum vulgare and } \\
\text { Trigonellafoenum-graecum as intercrops is not recommended for its dramatic effects on } \\
\text { germination efficiency and growth. }\end{array}$} \\
\hline Article Info & \\
\hline $\begin{array}{l}\text { Accepted: } \\
\text { 12 December } 2016 \\
\text { Available Online: } \\
\text { 10 January } 2017\end{array}$ & \\
\hline
\end{tabular}

\section{Introduction}

Genus Moringa is the only genus in family Moringa ceae and comprises 13 species from Africa, Madagascar, western Asia and the Indian subcontinent (Verdcourt, 1985). It is drought resistant, preferring regions with a wet/dry climate, but can grow in a wide range of habitats on a variety of soils. Moringa species are one of the most useful trees in the tropics and subtropics of Asia and Africa, with multiple uses. Moringa peregrine Forssk. is native to the region extending from the Dead Sea to Southern Arabia and northern Somalia (Dehshahri et al., 2012). In the past, Moringa peregrine was both an indigenous and a cultivated tree in Sudan (Jahn et al., 1986).
Moringa peregrine is widely grown in Saudi Arabia. It is a fast growing tree (Abd ElWahab, 1995). It has a grayish green bark, long, alternate leaves, and yellowish white to pink, showy, fragrant flowers (Boulos et al., 2000). The tree loses its leaves from December to January, though during droughts it may also lose its leaves at other times of the year (HDRA, 2002).

The Moringa tree is used for nutrition and medicine in many countries in MiddleEast. It is most praised for its nutritional abilities (Ghodsi et al., 2014). Ecology and nature of growth of the Moringa peregrina were studied by Zaghloul et al., (2010) and Gomaa 
and Pico (2011). It is an economic threat to agriculture in cropping areas for its probable allelopathic potentiality of their falling leaves. Allelopathic potentiality under field conditions can be utilized in different ways. For example, incorporation into the soil (Sati et al., 2004), aqueous extracts (Iqbal and Cheema, 2007a), or mix cropping /intercropping (Iqbal and Cheema, 2007b).

Intercropping; the agricultural practice of cultivating two or more crops in the same space at the same time is an old and commonly used cropping practice aimed to match efficiently crop demands to the available growth resources and labor.

The most common advantage of intercropping is the production of greater yield on a given piece of land by making more efficient use of the available growth resources using a mixture of crops of different rooting ability, canopy structure, height, and nutrient requirements based on the complementary utilization of growth resources by the component crops (Lithourgidis et al., 2011). One should be aware by the chemical interfering between the mixed crops in order to avoid undesirable potential effects of some crop on the others. Consequently, the main objective of the present study was to assess the probable allelopathic effects of Moringa peregrine on some growth attributes of the two economically important food crops; Hordeum vulgare and Trigonellafoenum-graecum in mixed cropping system.

\section{Materials and Methods}

\section{Preparation of donor species aqueous extracts}

Leaves of Moringa peregrine (donor species) were collected from cultivated fields at AlMadina governorate during the year 2016. Healthy leaves were selected carefully, washed in running tap water for removing the surface contaminants and dust and dried at room temperature for three days in shade. After drying, leaves were powdered using electric blender. Stock aqueous extract was obtained by soaking $50 \mathrm{~g}$ leaf powder in 500 $\mathrm{ml}$ of cold and boiled distilled water (10\% $\mathrm{w} / \mathrm{v})$ at room temperature $\left(20 \pm 2^{\circ} \mathrm{C}\right)$ for 24 hours with occasional shaking. The mixtures were filtered through two layers of cheese cloth and centrifuged for 20 minutes at 5000 rpmto remove particulate materials. The purified extracts were kept in the refrigerator at $5^{\circ} \mathrm{C}$. Series of subsequent dilutions $(2.5 \%$, $5.0 \%, 7.5 \%$ and $10 \%$ ) were prepared in addition to the control (distilled water) and tested for their effects on germination and seedling growth of Hordeum vulgare and Trigonellafoenum-graecum(recipient species).

\section{Germination Bioassay}

Petri-dish experiment was applied to investigate the potential allelopathic effects of aqueous extract of the donor species on germination percentage (GP), and radicle (RL) length of the recipient species. To accomplish this experiment, 10 seeds of the recipient species were arranged in $9 \mathrm{~cm}$ diameter Petri-dishes on 2 discs of Whatman No.1 filter paper under normal laboratory conditions with day temperature range of 25$30^{\circ} \mathrm{C}$ and night temperature range 20 $25^{\circ} \mathrm{C}$. Five $\mathrm{ml}$ of aqueous extracts of the donor species were added daily to three replicates. GP, and RL were recorded daily for successive eight days.

\section{Calculations}

\section{Germination percentage (GP)}

$\mathrm{GP}=$ (number of germinated seeds / total number of seeds) $\mathrm{x} 100$

\section{Statistical Analysis}

Data were analyzed by standard analysis of variance (ANOVA) and student's t-test with 
COSTAT 2.00 statistical analysis software (Zar, 1988). Differences were considered to be significant at $p \leq 0.05$.

\section{Results and Discussion}

Multiple cropping has been experienced in many parts of the world as a technique to maximize land productivity in a specific area in a growing season. However, plant litter or fallen leaves upon rainfall or irrigation water leaches out several allelochemicals which influence the growth of the same or other intercrops. The present study was conducted to investigate the biological interactions between Moringa peregrine leaves aqueous extract on the two recipient intercrops; Hordeum vulgare and Trigonellafoenumgraecum.

The allelopathic effects of Moringa peregrine leaves aqueous extract on germination percentage of Hordeum vulgare and Trigonellafoenum-graecum are presented in Table 1. Germination percentages of Hordeum vulgare was significantly affected by applying the different concentrations of Moringa peregrine leaves aqueous extract. The $\mathrm{F}$ values resulting from the application of analysis of variance (ANOVA), were high and the $\mathrm{P}$ values ranges from 0.012 to 0.001(Table 1).Phiri and Mbewe (2010) reported that addition of Moringa oleifera leaves extracts reduced germination percentage of groundnut seed and caused lower seedling survival.

Oluwafemi (2014) also found that the higher concentrations of Moringa oleifera fresh leaves extract suppress the seed germination and some growth parameters of Euphorbia heterophylla. Seedling survival got reduced as the concentration of extract increased which may suggest that Moringa oleifera possesses some bio-herbicidal properties.

The results of repeated t-test (Table 2) showed that Hordeum vulgareis more sensitive to Moringa peregrine leaves aqueous extract than Trigonellafoenumgraecum, and a concentration of $2.5 \%$ of that extract express the highest allelopathic effect on Hordeum vulgare.

Compared to the control, a gradual decrease in radicle lengths of the two recipient species was noticed along the gradual Moringa peregrinaleaves aqueous extract concentration (Table 3). Obviously, all concentration levels had significantly reduced radicle length of the two recipient species. The application of ANOVA test resulting in high $\mathrm{F}$ values for both tested species, and probability $\mathrm{p}$ were almost less than 0.001 .

Repeated t-test (Table 4) showed highly significant effect of all tested concentration levels of Moringa peregrine used in the experiment of the present study.

Reduction in radicle lengthsof Trigonellafoenum-graecum and Hordeum vulgare is directly proportional to the increase in concentration of donor aqueous extracts (Fig. 1and 2). Highest reductions were achieved using $10 \%$ aqueous extracts. The results of the present study indicate that the degree of radicle reduction of the recipient species is largely dependent on the concentration of the extracts of the donor species. These results are in agreement with Phiri and Mbewe (2010) who reported that addition of Moringa oleifera leaves extracts reduced hypocotyl formation and length resulting in delayed crop emergence and low field establishment of some legume crops. 
Table.1 Comparison between the studied treatments according to germination $\%$

\begin{tabular}{|c|c|c|c|c|c|c|c|c|}
\hline \multirow{3}{*}{$\begin{array}{c}\text { Treatment } \\
(\%)\end{array}$} & \multicolumn{8}{|c|}{ Germination \% } \\
\hline & \multicolumn{4}{|c|}{ Trigonellafoenum-graecum } & \multicolumn{4}{|c|}{ Hordeum vulgare } \\
\hline & 1 & 2 & 3 & 4 & 1 & 2 & 3 & 4 \\
\hline$\overline{\mathbf{0}}$ & $100.0 \pm 0.0$ & $100.0 \pm 0.0$ & $100.0 \pm 0.0$ & $100.0 \pm 0.0$ & $76.7 \pm 15.3$ & $100.0 \pm 0.0$ & $100.0 \pm 0.0$ & $100.0 \pm 0.0$ \\
\hline 2.5 & $96.7 \pm 5.8$ & $100.0 \pm 0.0$ & $100.0 \pm 0.0$ & $100.0 \pm 0.0$ & $53.3 \pm 15.3$ & $70.0 \pm 10.0$ & $70.0 \pm 10.0$ & $73.3 \pm 15.3$ \\
\hline 5.0 & $100.0 \pm 0.0$ & $100.0 \pm 0.0$ & $100.0 \pm 0.0$ & $100.0 \pm 0.0$ & $66.7 \pm 5.8$ & $80.0 \pm 10.0$ & $80.0 \pm 10.0$ & $80.0 \pm 10.0$ \\
\hline 7.5 & $96.7 \pm 5.8$ & $96.7 \pm 5.8$ & $96.7 \pm 5.8$ & $96.7 \pm 5.8$ & $93.3 \pm 11.5$ & $100.0 \pm 0.0$ & $100.0 \pm 0.0$ & $100.0 \pm 0.0$ \\
\hline 10.0 & $100.0 \pm 0.0$ & $100.0 \pm 0.0$ & $100.0 \pm 0.0$ & $100.0 \pm 0.0$ & $90.0 \pm 10.0$ & $95.0 \pm 5.0$ & $90.0 \pm 0.0$ & $90.0 \pm 0.0$ \\
\hline $\mathbf{F}$ & 0.750 & 1.000 & 1.000 & 1.000 & $5.614^{*}$ & $12.0^{*}$ & $12.750^{*}$ & $6.400^{*}$ \\
\hline $\mathbf{P}$ & 0.580 & 0.452 & 0.452 & 0.452 & $0.012^{*}$ & $0.001^{*}$ & $0.001^{*}$ & $0.008^{*}$ \\
\hline LSD at 0.05 & 6.649 & 4.701 & 4.701 & 4.701 & 22.051 & 12.214 & 11.516 & 14.867 \\
\hline
\end{tabular}

F: F test (ANOVA)

*: Statistically significant at $\mathrm{p} \leq 0.05$

Table.2 Repeated t-test before and after treatments according to germination $\%$

\begin{tabular}{|c|c|c|c|c|c|c|c|c|}
\hline \multirow{3}{*}{$\begin{array}{c}\text { Treatment } \\
(\%)\end{array}$} & \multicolumn{8}{|c|}{ P values } \\
\hline & \multicolumn{4}{|c|}{ Trigonellafoenum-graecum } & \multicolumn{4}{|c|}{ Hordeum vulgare } \\
\hline & 1 & 2 & 3 & 4 & 1 & 2 & 3 & 4 \\
\hline $2.5 \%$ vs Control & 0.290 & 1.000 & 1.000 & 1.000 & 0.040 & $<0.001^{*}$ & $<0.001^{*}$ & $0.003^{*}$ \\
\hline $5 \%$ vs Control & 1.000 & 1.000 & 1.000 & 1.000 & 0.336 & $0.004^{*}$ & $0.003^{*}$ & $0.013^{*}$ \\
\hline $7.5 \%$ vs Control & 0.290 & 0.145 & 0.145 & 0.145 & 0.123 & 1.000 & 1.000 & 1.000 \\
\hline $10 \%$ vs Control & 1.000 & 1.000 & 1.000 & 1.000 & 0.207 & 0.383 & 0.082 & 0.165 \\
\hline
\end{tabular}

*: Statistically significant at $\mathrm{p} \leq 0.05$

Table.3 Comparison between the studied treatments according to radicle length

\begin{tabular}{|c|c|c|c|c|c|c|c|c|}
\hline \multirow{3}{*}{$\begin{array}{c}\text { Treatment } \\
(\%)\end{array}$} & \multicolumn{8}{|c|}{ Radicle length (cm) } \\
\hline & \multicolumn{4}{|c|}{ Trigonellafoenum-graecum } & \multicolumn{4}{|c|}{ Hordeum vulgare } \\
\hline & 1 & 2 & 3 & 4 & 1 & 2 & 3 & 4 \\
\hline $\mathbf{0}$ & $8.7 \pm 1.5$ & $27.3 \pm 2.5$ & $32.7 \pm 2.5$ & $44.0 \pm 1.7$ & $22.7 \pm 2.5$ & $54.0 \pm 3.6$ & $70.0 \pm 1.0$ & $81.7 \pm 1.5$ \\
\hline 2.5 & $7.7 \pm 1.2$ & $22.7 \pm 3.8$ & $27.3 \pm 3.8$ & $38.3 \pm 2.1$ & $18.0 \pm 1.0$ & $50.7 \pm 2.1$ & $68.0 \pm 2.0$ & $76.0 \pm 1.0$ \\
\hline 5.0 & $6.0 \pm 1.0$ & $15.0 \pm 1.0$ & $20.3 \pm 1.5$ & $31.3 \pm 1.5$ & $14.3 \pm 0.6$ & $33.0 \pm 2.6$ & $52.3 \pm 2.5$ & $62.0 \pm 1.0$ \\
\hline 7.5 & $5.7 \pm 0.6$ & $12.3 \pm 1.5$ & $17.3 \pm 1.5$ & $22.3 \pm 2.1$ & $13.7 \pm 2.3$ & $28.3 \pm 2.1$ & $38.3 \pm 2.1$ & $48.7 \pm 2.1$ \\
\hline 10.0 & $5.3 \pm 1.5$ & $11.7 \pm 1.2$ & $15.7 \pm 1.2$ & $20.0 \pm 1.0$ & $10.3 \pm 1.5$ & $21.0 \pm 1.7$ & $31.7 \pm 1.5$ & $36.7 \pm 2.1$ \\
\hline $\mathbf{F}$ & $4.205^{*}$ & $28.112^{*}$ & $28.781^{*}$ & $104.70^{*}$ & $21.663^{*}$ & $97.353^{*}$ & $245.898^{*}$ & $403.077^{\prime}$ \\
\hline $\mathbf{P}$ & $0.030^{*}$ & $<0.001^{*}$ & $<0.001^{*}$ & $<0.001^{*}$ & $<0.001^{*}$ & $<0.001^{*}$ & $<0.001^{*}$ & $<0.001^{*}$ \\
\hline LSD $5 \%$ & 2.205 & 4.098 & 4.205 & 3.154 & 3.189 & 4.582 & 3.455 & 2.936 \\
\hline
\end{tabular}

F: F test (ANOVA)

*: Statistically significant at $\mathrm{p} \leq 0.05$ 
Table.4 Repeated t-test before and after treatments according to radicle length

\begin{tabular}{|c|c|c|c|c|c|c|c|c|}
\hline \multirow{3}{*}{$\begin{array}{c}\text { Treatment } \\
(\%)\end{array}$} & \multicolumn{8}{|c|}{ P values } \\
\hline & \multicolumn{4}{|c|}{ Trigonellafoenum-graecum } & \multicolumn{4}{|c|}{ Hordeum vulgare } \\
\hline & 1 & 2 & 3 & 4 & 1 & 2 & 3 & 4 \\
\hline$\%$ vs Control & 0.336 & $029^{*}$ & $018^{*}$ & $0.002^{*}$ & $0.009^{*}$ & 0.136 & 0.226 & $0.002^{*}$ \\
\hline & $022^{*}$ & $0.001^{*}$ & $<0.001^{*}$ & $<0.001^{*}$ & $<0.001^{*}$ & $<0.001^{*}$ & $<0.001^{*}$ & $<0.001^{*}$ \\
\hline $7.5^{5}$ & $0.013^{*}$ & $<0.001^{*}$ & $<0.001^{*}$ & $<0.001^{*}$ & $<0.001^{*}$ & $<0.001^{*}$ & $<0.001^{*}$ & $<0.001^{*}$ \\
\hline $10 \%$ & $0.007^{*}$ & $<0.001^{*}$ & $<0.001^{*}$ & $<0.001^{*}$ & $<0.001^{*}$ & $<0.001^{*}$ & $<0.001^{*}$ & $<0.001$ \\
\hline
\end{tabular}

*: Statistically significant at $\mathrm{p} \leq 0.05$

Fig 1 Radicle length of Trigonellafoenum-graecum under treatment with different concentrations of Moringa peregrine aqueous extract

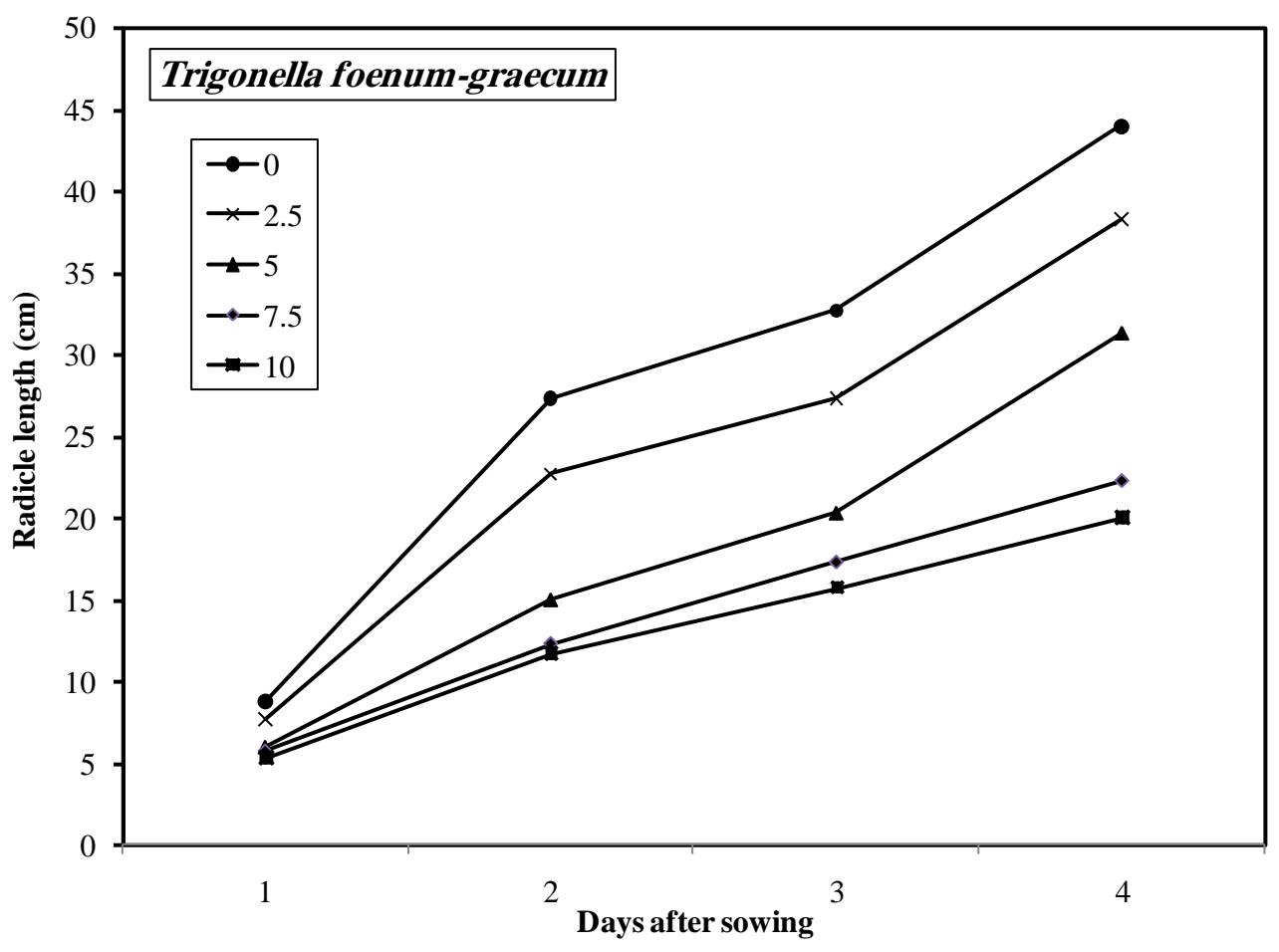


Fig 2 Radicle length of Hordeum vulgare seedlings under treatment with different concentrations of Moringa peregrina aqueous extract

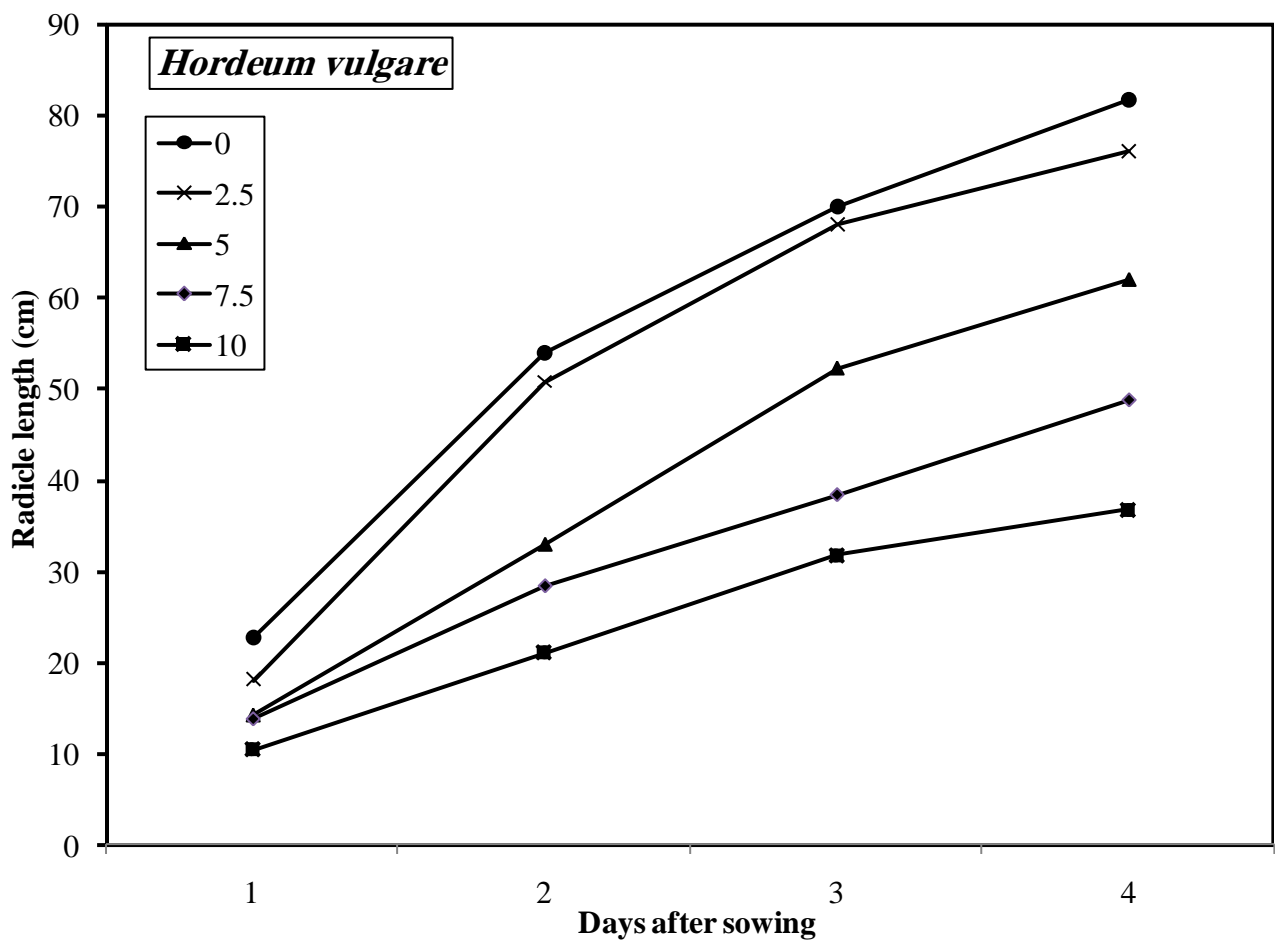

Abou-Zeid and El-Darier (2014) suggested thatthe reduction radicle lengths of Chenopodium album and Portulaca oleracea upon applying of Eucalyptus rostrata aqueous extract may be attributed to the presence of a diversity of allelochemicals in the extracts. Various studies have shown that, allelochemicals released by allelopathic plants do have negative effects large number of biochemical reactions on neighboring plant species (Oyerinde et al., 2009). The allelochemicals released to the environment by plant species, have significant effects on neighboring plants by reducing the rate of photosynthesis and respiration processes and finally reduce yield (Bogatek and Gniazdowska, 2007).

In conclusion, the cultivation of Moringa peregrina accompanied with Hordeum vulgare and Trigonellafoenum-graecumas intercrops is not recommended for its dramatic effects on germination efficiency and growth of the two species. Therefore, Moringa peregrina have to be considered as an allelopathic species posing risk in a rotation or an intercropping or mixed cropping system. With a view to alleviate its adverse effects on intercropping or subsequent crops, farmers should be conscious of leaves fallen from the mature trees and mixed with soil. The research needs further investigation to determine the nature of the chemical components of Moringa peregrinaleaves aqueous extractthen test their activities against the behavior of the intercrops.

\section{References}

Abd El-Wahab, R.H. 1995. Reproduction Ecology of Wild Trees and Shrubs in Southern Sinai, Egypt (M.Sc. diss.).Botany Department, Faculty of Science, Suez Canal University, Ismailia, Egypt.

Abou-Zeid, H.M. and EL-Darier, S.M. 2014. Allelotoxic activity of Eucalyptus 
rostrataSchlecht. on seed germination and seedling growth of Chenopodium album L. and Portulacaoleracea L. Int. J. Agronomy and Agri. Res., 4 (5): 39-50.

Bogatek, R. and Gniazdowska, A. 2007. ROS and Phytohormones in Plant allelopathic Interaction. Plant Signal. Behav., 4:317-318.

Boulos, L. 2000. In: Flora of Egypt Geraniaceae-Boraginaceae, vol.II. AlHadara Publishing, Cairo, Egypt.

Dehshahri, S., Wink, M., Afsharypuor, S., Asghari, G., Mohagheghzadeh, A. 2012. Antioxidant activity of methanolic leaf extract of Moringa peregrina (Forssk.) Fiori. Res. pharmaceutical sci., 7(2):111.

Ghodsi, R., Sadeghi, H.M., Asghari, G., Torabi, S. 2014. Identificationand cloning of putative water clarification genes of Moringa peregrina (Forssk.)Fiori in E. coli X11 blue cells. Adv. Biomed. Res., 27: 3-57.

Gomaa, N.H., Pico, F.X. 2011. Seed germination, seedling traits, andseed bank of the tree Moringa peregrina (Moringa ceae) in a hyperaridenvironment. Am. J. Bot., 98: 1024-1030.

HDRA. 2002. Moringa oleifera: a multi-purpose tree. <http://www.gardenorganic.org.uk/ pdfs/international_programme/Moringa .pdf>. HDRA - the Organic Organisation. Coventry, UK.

Iqbal, J. and Cheema, Z.A. 2007a. Effect of allelopathic crops water extracts on glyphosate dose for weed control in cotton. Allelopathy J., 19: 403-410.

Iqbal, J. and Cheema, Z.A. 2007b. Intercropping of field crops in cotton for management of purple nutsedge (Cyperusrotundus L.. Plant and Soil, 300: 163-171.

Jahn, S.A., Musnad, H.A., Heinz, B.(1986. The tree that purifies water: cultivating multipurpose Moringa ceae in the Sudan.
Unasylva, 38:23-28.

Lithourgidis, A.S., Dordas, C.A, Damalas, C.A. and Vlachostergios, D.N. 2011. Annual intercrops: an alternative pathway for sustainable agriculture. Australian J. Crop Sci., 5: 396-410.

Oluwafemi, A.B. 2014. Allelopathic effects of Moringa olifera on the germination and seedling survival of Euphorbia heterophylla L. GJBAHS, 3(1):195-198.

Oyerinde, R.O., Otusanya, O.O. and Akpor, O.B. 2009. Allelopathic effect of Tithoniadiversifolia on the germination, growth and chlorophyll contents of maize (Zea mays L.. Scientific Res. Essay, 4(12): 1553-1558.

Phiri, C. 2010. Influence of Moringa oleifera Leave extracts on germination and early seedling development on major cereals. Agri. Biol. J., 1: 774-777.

Sati, S.C., Palaniraj, R., Narwa, S.S., Gaura, R.D. and Dahiya, D.S. 2004.Effects of decomposing wheat and barley residues on the germination and seedling growth of Trianthemaportulacastrum and Echinochloacolonum. International conference: Allelopathy in Sustainable Terrestrial and Aquatic Ecosystem. August 23-25, Haryana Agricultural University.Hisar-125004, India.

Verdcourt, B. 1985. A synopsis of the Moringa ceae. Kew Bull., 40: 1-23.

Zaghloul, M.S., Abd El-Wahab, R.H., Moustafa, A.A. 2010. Ecological assessment and phenotypic and fitness variation of sinai's remnant populations of Moringa peregrina. Appl. Ecol. Environ. Res., 8: 351-366.

Zar, J.H. 1988. Bio statistical Analysis. PrenticeHall. Incorporate in New Jersey 718pp.

\section{How to cite this article:}

Ameera Amin Aytah. 2017. Allelopathic Effect of Moringa peregrina Forssk. on Germination and Early Seedling Development of Two Common Food Intercrops. Int.J.Curr.Microbiol.App.Sci. 6(1): 161-167. doi: http://dx.doi.org/10.20546/ijcmas.2017.601.020 